KINGA LISOWSKA

Uniwersytet Warmińsko-Mazurski w Olsztynie, Polska - University of Warmia and Mazury in Olsztyn, Poland

MaJKa ŁoJKo

Uniwersytet Warmińsko-Mazurski w Olsztynie, Polska - University of Warmia and Mazury in Olsztyn, Poland

\title{
Wioski tematyczne w upowszechnianiu dziedzictwa kulturowego Warmii i Mazur jako przykład edukacji i przedsiębiorczości regionalnej
}

\section{Thematic Villages in the Dissemination of the Cultural Heritage of Warmia and Mazury as an Example of Education and Regional Entrepreneurship}

Streszczenie: Wioski tematyczne są przykładem jednej z niszowych form przedsiębiorczości społecznej, prowadzącej produkcję i usługi służące ożywieniu społeczno-gospodarczemu obszarów wiejskich oraz rozwojowi edukacji z zakresu dziedzictwa kulturowego. Województwo warmińsko-mazurskie ma zdecydowanie charakter rolniczy, a jego gospodarka wykazuje silne związki z zasobami naturalnymi, co sprzyja podejmowaniu działań opartych na lokalnej przedsiębiorczości z wykorzystaniem tego typu inicjatyw. Celem artykułu jest zaprezentowanie zakresu i kierunków działań wiosek tematycznych na Warmii i Mazurach jako innowacyjnego elementu rozwoju przedsiębiorczości społeczeństwa wielopokoleniowego $\mathrm{w}$ upowszechnianiu i edukacji na rzecz dziedzictwa kulturowego tego regionu. Podjęto próbę odpowiedzi na pytanie: $\mathrm{W}$ jaki sposób wioski tematyczne jako przedsiębiorstwa społeczne poprzez różnorodne inicjatywy edukacyjno-kulturalne i usługi agroturystyczne mogą przyczynić się do pobudzenia i rozwoju gospodarki wiejskiej? w odniesieniu do konkretnych przykładów wykorzystania dziedzictwa kulturowego w rozwoju przedsiębiorczości w regionie. W artykule zastosowano kwerendę literatury przedmiotu oraz posłużono się metodą obserwacji uczestniczącej prowadzonej bezpośrednio w badanych wioskach. W celu zdiagnozowania potencjału rozwojowego i edukacyjnego warmińsko-mazurskich wiosek tematycznych przeprowadzono badania empiryczne z wykorzystaniem kwestionariusza wywiadu.

Abstract: Thematic villages are an example of one of the niche forms of social entrepreneurship, handling production and services for the socio-economic recovery of rural areas and the development of education in the field of cultural heritage. The Warmińsko-Mazurskie Voivodeship is definitely agricultural, and the economy has strong links with natural resources, which favours undertaking actions based on local entrepreneurship using such initiatives. The aim of the article is to present the scope and directions of activities of thematic villages in Warmia and Mazury as an innovative element of entrepreneurship development of a multi-generational society in dissemination and education for the cultural 
heritage of the region. The paper attempts to answer the following questions: How can thematic villages as social enterprises contribute to stimulating and developing the rural economy through various educational and cultural initiatives and agrotourism services? The paper includes references to specific examples of the use of cultural heritage in the development of entrepreneurship of different age groups in the region. The literature query of the subject and the method of participant observation directly conducted in the examined villages were used. In order to diagnose the development and educational potential of the Warmian-Masurian thematic villages, empirical research was conducted using an interview questionnaire.

Słowa kluczowe: dziedzictwo kulturowe; edukacja regionalna; przedsiębiorczość społeczna; wioski tematyczne

Keywords: cultural heritage; regional education; social entrepreneurship; thematic villages

Otrzymano: 23 grudnia 2019

Received: 23 December 2019

Zaakceptowano: 19 kwietnia 2020

Accepted: 19 April 2020

\section{Sugerowana cytacja/Suggested citation:}

Lisowska, K., Łojko, M. (2020). Wioski tematyczne w upowszechnianiu dziedzictwa kulturowego Warmii i Mazur jako przykład edukacji i przedsiębiorczości regionalnej. Przedsiębiorczość Edukacja [Entrepreneurship - Education], 16(1), 184-197. doi: 10.24917/20833296.161.15

\section{Wstęp}

Problematyka wiosek tematycznych zajmuje niewiele miejsca w literaturze naukowej zarówno w Polsce, jak i na świecie. Pomimo że inicjatywy te funkcjonują w rzeczywistości społecznej od wielu lat, to nadal istnieje niedostatek kompleksowych publikacji naukowych z tego obszaru. Idea zakładania wiosek tematycznych w ostatnich latach stała się zjawiskiem bardzo popularnym oraz sposobem ożywienia przedsiębiorczości wiejskiej. Wioski tematyczne można traktować jako nowoczesne projekty rozwoju przedsiębiorczości przeznaczone dla różnych grup wiekowych oraz jako przykład innowacyjności w turystyce, który zyskuje w regionie coraz większą popularność. Z założenia to przedsięwzięcie, a zarazem innowacyjny sposób angażowania i aktywizacji społeczno-zawodowej mieszkańców wsi, dzięki któremu mają oni możliwość pozyskania alternatywnego źródła dochodu.

Przy tworzeniu wiosek tematycznych kluczowym zadaniem jest przygotowanie odpowiednich programów edukacyjnych opartych na istniejących walorach kulturowych, turystycznych i przyrodniczych. Tworzenie wiosek tematycznych jest ciekawym i nowym pomysłem na poprawę ekonomicznej i zawodowej sytuacji mieszkańców wsi, zwłaszcza tych położonych peryferyjnie, $\mathrm{z}$ dala od miast i dobrych dróg. Wioski takie powstają najczęściej tam, gdzie upada przemysł i ludzie zmuszeni są do poszukiwania innych perspektyw i możliwości rozwoju (Roman, Niedziółka, 2017). Do takich terenów należy region Warmii i Mazur, w którym unikatowe walory środowiska naturalnego, różnorodność narodowościowa oraz zróżnicowane dziedzictwo kulturowe odwołujące się do autentycznej kultury wiejskiej są doskonałym polem do tworzenia tego typu przedsięwzięć. Celem głównym artykułu jest przedstawienie zakresu i kierunków działań wsi tematycznych na Warmii i Mazurach jako innowacyjnego elementu rozwoju przedsiębiorczości 
społeczeństwa wielopokoleniowego w upowszechnianiu i edukacji na rzecz dziedzictwa kulturowego tego regionu. Innowacyjność jest tu rozumiana jako korzystna, twórcza i oryginalna zmiana w różnych obszarach działalności organizacji (w tym przypadku wiosek tematycznych), wnosząca nowość i postęp w stosunku do stanu istniejącego, ocenianego pozytywnie w świetle kryteriów efektywności organizacji (Kozioł, Karaś, 2015).

Zasadnicza teza artykułu zawiera się w stwierdzeniu, że wioski tematyczne dzięki różnorodnym działaniom edukacyjnym i przedsiębiorczym w istotny sposób przyczyniają się do innowacyjnego ożywienia i rozwoju gospodarki wiejskiej w regionie Warmii i Mazur.

Prezentowany artykuł jest przyczynkiem do podjęcia dalszych dyskusji na temat tworzenia wiosek tematycznych w Polsce na terenach bogatych w zasoby kulturowe.

\section{Wioska tematyczna - zagadnienia wstępne}

Wieś tematyczna to innowacyjne przedsięwzięcie realizowane dzięki zaangażowaniu i aktywności mieszkańców skupionych na realizacji wspólnie wybranego pomysłu na lokalny biznes, który opiera się na wykorzystaniu lokalnych tradycji, zasobów, potencjału i umiejętności/talentów mieszkańców. Inspiracją do realizacji tego typu działań są pomysły lokalnych liderów, przedstawicieli różnych funkcjonujących w lokalnym środowisku organizacji oraz zaangażowanych w budowanie społecznego przedsięwzięcia mieszkańców. Zdaniem S. Wacięgi, wioska tematyczna jest przykładem inicjatywy społeczno-gospodarczej, w wyniku której mieszkańcy tworzą własną ofertę turystyczną opartą na wybranym temacie przewodnim, przyczyniającym się do kreowania wizerunku miejscowości. Dzięki takim działaniom wioska staje się ośrodkiem turystycznym opartym na pomysłowości, wiedzy i kreatywności mieszkańców zaangażowanych w jej działalność. Niewątpliwym atutem tego typu wioski jest relatywnie korzystna relacja nakładów do efektów - działalność wioski opiera się przede wszystkim na oryginalnym pomyśle oraz wykorzystaniu dostępnych zasobów, m.in. walorów krajobrazowych, dziedzictwa kulturowego, pomysłów i talentów jej mieszkańców (Wacięga, 2011).

Pomysł na tworzenie wsi tematycznych w Europie pojawił się stosunkowo niedawno, dopiero po 1990 r. Pierwsze tego typu przedsięwzięcia powstały na terenie Dolnej Austrii, a następne w Niemczech, Belgii, Francji i Portugalii za sprawą programu „Leader”, ukierunkowanego na rozwój obszarów wiejskich. Inicjatorem było stowarzyszenie Lower Austrian Village and Urban Renewal Project. Najstarszą wioską tematyczną w Europie jest Makowa Wioska Armschlang w Austrii (Kowalska, 2019). W przypadku krajów pozaeuropejskich wioski występują m.in. w USA, Kanadzie, Australii, Chinach i Korei Południowej (Sala, 2016).

Do Polski nurt ten dotarł nieco później. Wprawdzie już w 1998 r. podjęto pierwsze inicjatywy i próby tworzenia tego typu przedsięwzięcia w województwie wielkopolskim (w gminie Wierzbinek), jednak formalnie wioski tematyczne zaczęły aktywnie działać w 2003 r., najpierw w dwóch gminach województwa zachodniopomorskiego (Czapniewska, 2018). Inicjatywy tworzenia wiosek tematycznych w Polsce na początku napotykały na wiele problemów. Mieszkańcy wsi, przeważnie zniechęceni do spółdzielczości i prac społecznych, z dużą rezerwą podchodzili do wspólnej własności i wspólnych działań (Idziak, 2008). W miarę upływu czasu inicjatywy te przyjęły charakter dynamiczny, co zaowocowało powstawaniem i rozwojem wiosek. Na początku związane były z występującymi na danych terenach produktami lokalnymi i najczęściej tworzyli je zaangażowani 
społecznie mieszkańcy, jako inicjatywy oddolne, lub przez stowarzyszenia (Idziak, 2019). W miarę upływu czasu oferty wsi tematycznych zostały wzbogacone o nowe pomysły i produkty, które przyczyniły się do stworzenia unikatowego i oryginalnego lokalnego klimatu na bazie zasobów przyrodniczych, kulturowych czy historycznych danego regionu.

Aktualnie w Polsce aktywnie działa ok. 200 wsi tematycznych, a z każdym rokiem przybywa tego typu miejsc na mapie. Wioski tematyczne funkcjonują praktycznie w każdym województwie. Chociaż ze statystycznego punktu widzenia są one zjawiskiem marginalnym, to jednak wzbudzają spore zainteresowanie badaczy ze względu na swój unikalny charakter związany z innowacyjnym sposobem wykorzystywania tradycyjnego rolnictwa (Kłoczko-Gajewska, 2018) oraz działania z obszaru edukacji regionalnej, które służą upowszechnieniu i popularyzacji dziedzictwa kulturowego danego terenu.

\section{Idea przedsiębiorczości społecznej w tworzeniu wiosek tematycznych}

Działalność wiosek tematycznych jest terenem praktyki wielu podmiotów sektora ekonomii społecznej. Sektor ten określany jest również jako gospodarka społeczna lub przedsiębiorczość społeczna. W tym przypadku idea przedsiębiorczości społecznej doskonale wkomponowuje się w koncepcję tworzenia inicjatyw, których celem jest aktywizacja społeczna i ekonomiczna mieszkańców wsi, pobudzenie przedsiębiorczości wiejskiej, a tym samym - przeciwdziałanie wykluczeniu i marginalizacji tych środowisk. Przedsiębiorczość społeczna traktowana jest jako działalność organizacji, które łączą cele gospodarcze z celami społecznymi, przy czym te drugie mają znaczenie nadrzędne. Obejmuje szeroki zakres praktyk, których mają przede wszystkim doprowadzić do poprawy warunków społecznych, gospodarczych i środowiskowych określonych wspólnot lokalnych oraz ich poszczególnych jednostek (Loxley, 2007).

Sektor ekonomii społecznej integruje różne podmioty gospodarki, które nie są zorientowane jedynie na tworzenie i dystrybucję kapitału, ale przede wszystkim na realizację celów społecznych, wśród których najważniejsze są aktywizacja zawodowa i tworzenie miejsc pracy dla osób najbardziej oddalonych od rynku pracy (Pearce, 2003). Nie sposób pominąć funkcji tego sektora w kontekście rozwoju przedsiębiorczości wiejskiej. Najważniejsze jego znaczenie wynika z: możliwości uzyskiwania dodatkowych źródeł dochodów dla mieszkańców; pozyskiwania dodatkowych dochodów przez gminy; rozwoju lokalnej infrastruktury, podwyższania standardów i warunków życia mieszkańców wsi; tworzenia dodatkowych miejsc pracy, co w konsekwencji prowadzi do zmniejszenia poziomu bezrobocia na wsi; możliwości zdobywania nowych umiejętności; poprawy estetyki obszarów wiejskich; możliwości upowszechniania dziedzictwa kulturowego wsi - promocja miejscowości i budowa jej wizerunku (Podołowski, 2011).

Jak widać, prowadzenie działalności w formie wioski tematycznej przynosi mieszkańcom wsi wiele korzyści. Na plan pierwszy wysuwają się korzyści społeczno-ekonomiczne i społeczno-kulturowe, które łączą się z kreowaniem nowych miejsc pracy, działaniami na rzecz ochrony dziedzictwa przyrodniczego i kulturowego regionów oraz możliwością uzyskiwania dodatkowych źródeł dochodów. Zwiększenie dochodów wiąże się także z polepszeniem standardu oraz jakości życia ludności wiejskiej. Nie bez powodu w rozwoju tego typu przedsiębiorczości upatruje się szansę na rewitalizację obszarów wiejskich, wyznaczając jej rolę jednego z instrumentów odbudowy ich żywotności kulturowej i ekonomicznej (Łojko, 2011). 
Edukacja w zakresie dziedzictwa kulturowego jako czynnik rozwoju przedsiębiorczości lokalnej

Dziedzictwo kulturowe jako determinant specyfiki i swoistości regionów należy do czynników endogenicznych utożsamianych z czynnikami miękkimi, takimi jak: kapitał społeczny, tożsamość regionalna, wspólne wzorce kulturowe czy tradycja (Hełpa-Liszkowska, 2013). Dziedzictwo kulturowe jest nośnikiem przenikających się wartości ekonomicznych, historycznych, naukowych, artystycznych, społecznych, edukacyjnych i gospodarczych. Jak twierdzi M. Murzyn-Kupisz, potencjał dziedzictwa kulturowego dla rozwoju lokalnego przejawia się w jego wartościowaniu przez depozytariuszy i interesariuszy. W tym kontekście dziedzictwo postrzegane jest jako jedna z podstaw przedsiębiorczości regionalnej, obszar innowacji i konkurencyjności oraz produkt rynkowy wpływający na jakość życia w regionie. P. Legutko-Kobus ekonomiczne oddziaływanie dziedzictwa wiąże $\mathrm{z}$ sektorem i branżami dziedzictwa kulturowego i ich bezpośrednim oddziaływaniem na rozwój gospodarczy, a także z oddziaływaniem mnożnikowym i inspirowaniem działań przedsiębiorczych (Legutko-Kobus, 2016). Dziedzictwo kulturowe jest więc stymulatorem rozwoju gospodarczego regionu bezpośrednio generującym działalność ekonomiczną w sektorach, w których powstanie, przetrwanie i rozwój zależy od jego zasobu: turystyki kulturowej, branży kreatywnej, rynku nieruchomości zabytkowych, rzemiosła tradycyjnego, tradycyjnej uprawy, popularyzacji, informacji, edukacji dziedzictwa; rynku i sztuki antyków; branży ochrony dziedzictwa (Legutko-Kobus, 2016). Nie powinno zatem stanowić ono jedynie przedmiotu ochrony, ale powinno również tworzyć potencjał do rozwoju społeczno-gospodarczego regionu (Purchla, 2011).

Ze względu na podjętą tematykę, edukację w zakresie dziedzictwa kulturowego regionu należy traktować jako czynnik miękki, endogeniczny w kontekście bezpośredniego i pośredniego oddziaływania na rozwój przedsiębiorczości w regionie poprzez: popularyzację, informację i realizację programów edukacyjnych, takich jak: warsztaty z zakresu historii, kultury, zwyczajów, gwary; obyczajów; nauczanie tradycyjnych profesji i zawodów; zajęcia artystyczne; rekonstrukcje historyczne; festiwale; kiermasze oraz wszelką ofertę podmiotów państwowych, prywatnych, organizacji i stowarzyszeń, formalnych i nieformalnych inicjatyw lokalnych w obszarze upowszechniania i wzrostu świadomości tożsamości regionalnej społeczności. Edukacja z zakresu dziedzictwa kulturowego jest także specyficzną formą edukacji regionalnej wykraczającą poza mury szkolne, którą D. Jankowski utożsamia z: wprowadzeniem jednostek i małych grup społecznych $\mathrm{w}$ tradycję oraz aktualne życie społeczno-kulturalne danego środowiska lokalnego; ułatwieniem im funkcjonowania jako podmiotów społecznych i społeczno-gospodarczych; realizacją własnych aspiracji przy wspólnym wykorzystaniu zasobów lokalnych - przyrodniczych, gospodarczych, społecznych i kulturalnych (Jankowski, 1990).

Potencjał rozwojowy i edukacyjny warmińsko-mazurskich wiosek tematycznych dyskusja wyników

Województwo warmińsko-mazurskie jako jeden z najciekawszych kulturowo i historycznie regionów Polski odznacza się unikatowymi walorami historycznymi i przyrodniczo-krajobrazowymi, które sprzyjają rozwojowi przedsiębiorczości społecznej na terenach wiejskich, czego doskonałym przykładem są wioski tematyczne. 
Według danych Regionalnego Ośrodka Polityki Społecznej w Olsztynie na terenie Warmii i Mazur funkcjonuje 25 wiosek tematycznych, zlokalizowanych w różnych częściach województwa. Wioski te można określić jako nowoczesne projekty promujące turystykę w mniejszych miejscowościach i wsiach o zróżnicowanym profilu działalności. Ich inicjatorami są przede wszystkim stowarzyszenia i fundacje lokalne. Powody utworzenia wsi tematycznych były różne. Osoby objęte badaniem w pierwszej kolejności wskazywały na potrzebę promocji wsi i jej walorów, chęć aktywizacji i integracji mieszkańców, jak również na możliwość wykorzystania wyjątkowego dziedzictwa historyczno-kulturowego tych miejscowości. Praktycznie wszystkie wioski mają jasno sprecyzowaną strategię rozwoju i kierunek działań, co zdecydowanie wzmacnia ich potencjał ekonomiczny i społeczny. Badane wsie specjalizują się w różnego typu działaniach, w związku z czym mają różny motyw przewodni, najczęściej związany z zasobami lub produktami lokalnymi. Jednak niektóre oferty opierają się na motywach irracjonalnych, niezwiązanych z danym miejscem (Czapniewska, 2018: 160). Przy tworzeniu wiosek główna aktywność jej liderów ukierunkowana jest na przygotowanie odpowiedniej oferty programowej, zajęć warsztatowych czy też programów edukacyjnych mających za zadanie przekazywanie i kultywowanie wierzeń i tradycji regionu. Prowadzenie wioski tematycznej, opartej na atrakcjach nawiązujących do charakterystycznych wątków danych miejscowości, przyczynia się do zwiększenia atrakcyjności tego obszaru. Propozycje badanych wsi często są też włączane do oferty turystycznej, stając się dodatkową atrakcją edukacyjną i kulturalną regionu.

$\mathrm{Na}$ podstawie przeprowadzonych wywiadów można określić rodzaje specjalizacji badanych wiosek (tabela 1), które bazując na zasobach materialnych i niematerialnych miejscowości, oferują różne produkty i usługi. W badanych wioskach prowadzone są warsztaty i gry edukacyjne oraz znajdują się ścieżki edukacyjne, poprzez które przekazywana jest wiedza w zakresie upowszechniania dziedzictwa kulturowego Warmii i Mazur. Organizowane są także różnego rodzaju festyny, wystawy czy spotkania okolicznościowe, podczas których mieszkańcy wioski mogą sprzedawać własne wypieki, miody, nalewki, płody rolne czy też rękodzieła ludowe. Urozmaicona oferta usług i produktów wpływa na dynamikę ożywienia wiosek, przyciąga turystów i generuje popyt na danym terenie, stwarzając jednoczenie możliwość rozwoju innych branż, gdyż wymusza konieczność podejmowania i rozszerzania działalności handlowej, gastronomicznej, transportowej, edukacyjnej, rekreacyjno-sportowej, przewodnickiej itp. (Roman, Niedziółka, 2017).

Działalność promocyjna badanych wiosek jest jednym z elementów marketingu miejsc, czyli w całości zaplanowanych i skoordynowanych działań zmierzających do podniesienia atrakcyjności turystycznej, gospodarczej i społeczno-kulturowej danego miejsca (Sowier-Kasprzyk, 2011).

Jednym z kluczowych i skutecznych działań w tym zakresie jest tworzenie pozytywnego wizerunku, dzięki któremu tego rodzaju wioski są odpowiednio promowane i rozpoznawalne, co z kolei wpływa na powodzenie ich działań. W celu przygotowania interesującej oferty we wsiach tematycznych podejmuje się różnorodne działania promocyjne, które określają specjalizację miejscowości i kierunki jej rozwoju. Z przeprowadzonych badań wynika, że przedstawiciele badanych wsi wyraźnie akcentują potrzebę oryginalności i unikatowości. Nie jest jednak łatwo uniknąć powtarzania pomysłów innych, a być może nie należy tego czynić, gdyż, jak podkreślają Ł. Malec-Kornajew i J. Kania, powtarzalność częściowo odzwierciedla dziedzictwo kulturowe wsi polskiej i może być postrzegana przez odbiorców jako zjawisko pozytywne, bowiem lubimy to, co jest nam znane (Malec-Kornajew, Kania, 2015). 
Tabela 1. Specjalizacje warmińsko-mazurskich wsi tematycznych

\begin{tabular}{|l|l|}
\hline \multicolumn{1}{|c|}{ Rodzaj oferty } & \multicolumn{1}{c|}{ Wyszczególnienie } \\
\hline Warsztaty edukacyjne & $\begin{array}{l}\text { Warsztaty: artystyczne, ekologiczne, z zakresu edukacji regionalnej, } \\
\text { warsztaty garncarskie, wikliniarskie, bibułkarstwo, decoupage, } \\
\text { kulinarne, chóralne, teatralne }\end{array}$ \\
\hline Gry terenowe & Gry terenowe typu Quest (w j. polskim i angielskim) \\
\hline $\begin{array}{l}\text { Oznakowane ścieżki } \\
\text { edukacyjne }\end{array}$ & Ścieżki: ekologiczno-edukacyjne, dydaktyczno-historyczne \\
\hline $\begin{array}{l}\text { Wydarzenia, imprezy, } \\
\text { festyny, pikniki }\end{array}$ & $\begin{array}{l}\text { Wojewódzki Festiwal Młodych Talentów dla dzieci w wieku 6-10 lat; } \\
\text { Ogólnopolski Otwarty Turniej Chórów „O Miecz Juranda”, } \\
\text { Ogólnopolski Festiwal Piosenki Dziecięcej i Młodzieżowej „Polska } \\
\text { muzyka lat 60, 70 i 80” im. Grażyny Świtały, Festiwal Kulinarny } \\
\text { Bulwa”, Impreza Kulinarna „Gęsina”, Lato w Teatrze, Lato Kulturalne - } \\
\text { cykl koncertów, turniej o miecz Herkusa Monte, festyn „Bocianie lato } \\
\text { w Żywkowie” }\end{array}$ \\
\hline Wystawy stacjonarne & $\begin{array}{l}\text { Izby pamięci, minimuzea, wystawy fotografii przyrodniczej podczas } \\
\text { imprez plenerowych i festynów }\end{array}$ \\
\hline $\begin{array}{l}\text { Organizowanie imprez } \\
\text { okolicznościowych/ } \\
\text { rodzinnych }\end{array}$ & $\begin{array}{l}\text { Wesela, komunie i inne imprezy okolicznościowe, spotkania z historią, } \\
\text { przyrodą, prowadzenie zielonych lekcji, aktywne spotkania w gminnych } \\
\text { centrach rekreacji }\end{array}$ \\
\hline
\end{tabular}

Źródło: opracowanie własne

W badanych wioskach szczególnie dba się o aspekt wizualny i promocyjny. Poprzez system informacji przestrzennej - drogowskazy, witacze, tablice informacyjne, a także odpowiednie stroje - prowadzone są działania edukacyjno-promocyjne tych miejscowości. Każda z badanych wsi ma także własną stronę internetową i konto na Facebooku, dzięki czemu może na bieżąco prezentować i uaktualniać swoją ofertę w internecie. Również samorządy lokalne promują tematykę wsi tematycznych m.in. przez: umieszczanie na stronie internetowej powiatu/gminy informacji na temat działań wiosek tematycznych, promocję w lokalnej telewizji, prowadzenie oddzielnych zakładek na portalach internetowych oraz publikację materiałów dotyczących tego rodzaju przedsięwzięć. Każda $\mathrm{z}$ badanych wiosek stara się przyciągnąć do siebie unikatowym produktem turystycznym oraz nowatorskimi pomysłami. Z ich oferty korzystają zarówno grupy, jak i turyści indywidualni. Każdego roku miejscowości te są odwiedzane przez ok. 3 tys. turystów zarówno z Polski, jak i z zagranicy.

Warmińsko-mazurskie wsie tematyczne stały się determinantem rozwoju lokalnej infrastruktury oraz podwyższenia standardów i warunków życia mieszkańców wsi. Powstała nowa, zagospodarowana przestrzeń wiejska, która stanowi walor przewagi konkurencyjnej regionu w obszarze turystyki oraz sektorze edukacyjnym. Odnotowano wzrost możliwości korzystania z lokalnego potencjału kulturowego. Ekonomiczne i edukacyjne produkty lokalne, oferty turystyczne, lokale gastronomiczne, miejsca użyteczności publicznej oraz bogata oferta programów warsztatów i kursów o tematyce regionalnej wzmocniły kapitał społeczny i rozwój społeczno-gospodarczy terenów wiejskich. We wszystkich wsiach pracę rozpoczęły podmioty ekonomii społecznej w postaci spółdzielni socjalnych, fundacji i stowarzyszeń, które podjęły współpracę z lokalnymi rzemieślnikami i artystami. Utworzono dodatkowe miejsca pracy, co umożliwiło zmniejszenie 
bezrobocia na badanych obszarach i uzyskiwanie dodatkowych dochodów. Ponadto, mieszkańcy nabyli nowe kompetencje i umiejętności, poprawiając tym samym swoją sytuację na rynku pracy.

W tak zmienionej rzeczywistości społeczno-ekonomicznej uaktywniła się wspólna działalność mieszkańców na rzecz estetyki wiejskiej i lokalnego dziedzictwa. Powstała sieć regionalnych powiązań, złożona z przedstawicieli wiosek tematycznych oraz społeczności Warmii i Mazur, gwarantująca wzajemne wsparcie w procesie: pozyskiwania funduszy zewnętrznych, rozwoju potencjału, reklamy usług oraz tworzenia przedsiębiorstw ekonomii społecznej. Na obszarze działalności wsi tematycznych wykształciło się powszechne zrozumienie potrzeby upowszechniania spuścizny kulturowej i historycznej, która stała się nośnikiem rozwoju ekonomicznego.

Na podstawie przeprowadzonych badań rozwój społeczno-gospodarczy wsi Warmii i Mazur, stymulowany działalnością wiosek tematycznych, można scharakteryzować przy użyciu dwóch kategorii: obszaru rozwoju oraz jego charakterystycznych elementów.

Tabela 2. Rola wsi tematycznej w rozwoju obszaru wiejskiego

\begin{tabular}{|c|c|}
\hline Obszar rozwoju & Charakterystyka \\
\hline Przestrzeń wiejska & $\begin{array}{l}\text { - Rozbudowa infrastruktury wiejskiej: boisk, świetlic, siłowni } \\
\text { zewnętrznych, placów zabaw, placów centralnych wraz z zielenią, } \\
\text { dróg; tablic informacyjnych, mostów, nowych oznakowań wsi } \\
\text { - Turystyczne zagospodarowanie przestrzeni wiejskiej: cmentarzy } \\
\text { wojennych i historycznych, szlaków kulturowych i turystycznych }\end{array}$ \\
\hline $\begin{array}{l}\text { Aktywizacja na rzecz } \\
\text { dziedzictwa }\end{array}$ & $\begin{array}{l}\text { - Organizacja imprez kulturalnych i uczestnictwo w takich imprezach: } \\
\text { festiwale kulturalne oraz kulinarne, kiermasze, odpusty, dożynki, } \\
\text { dni folkloru i sztuki, koncerty patriotyczne } \\
\text { - Reaktywacja świąt regionalnych, takich jak Lipcówka, zjazdy } \\
\text { Żywkowiaków, Kiermasz Warmiński, Gminne Święto Plonów } \\
\text { - Wspólna troska o zewnętrzne walory wiejskie: odnowa i odbudowa } \\
\text { wsi przez społeczność lokalną } \\
\text { - Organizowanie wielopokoleniowych imprez okolicznościowych }\end{array}$ \\
\hline Rozwój ekonomiczny & $\begin{array}{l}\text { - Działalność spółdzielni socjalnych i stowarzyszeń } \\
\text { - Prowadzenie punktów gastronomicznych z lokalnymi potrawami } \\
\text { - Tworzenie produktów turystycznych: obiektów turystycznych, } \\
\text { zabudowy wiejskiej, szlaków kulturowych i turystycznych, } \\
\text { przewodników } \\
\text { - W obszarze hotelarstwa: tworzenie miejsc noclegowych } \\
\text { z wykorzystaniem starych budynków gospodarczych } \\
\text { - Tworzenie produktów i przedsięwzięć edukacyjnych } \\
\text { - Tworzenie punktów sprzedaży rękodzieła i kulinarnych produktów } \\
\text { regionalnych }\end{array}$ \\
\hline $\begin{array}{l}\text { Sieć lokalnych } \\
\text { powiązań }\end{array}$ & $\begin{array}{l}\text { - Współpraca z innymi wsiami tematycznymi: promocja marek } \\
\text { lokalnych, realizacja przedsięwzięć edukacyjnych, pozyskiwanie } \\
\text { funduszy zewnętrznych oraz przygotowywanie wydawnictw } \\
\text { turystycznych i edukacyjnych, tworzenie sieci internetowej }\end{array}$ \\
\hline $\begin{array}{l}\text { Wykorzystanie } \\
\text { lokalnych zasobów }\end{array}$ & $\begin{array}{l}\text { - Zagospodarowanie przestrzeni przyrodniczo-historycznej } \\
\text { oraz nabywanie umiejętności ich promocji } \\
\text { - Nabywanie kompetencji do prowadzenia lokalnych działań } \\
\text { ekonomicznych }\end{array}$ \\
\hline
\end{tabular}

Źródło: opracowanie własne 
Potencjał dziedzictwa kulturowego dla rozwoju lokalnego przejawia się w jego wartościowaniu przez depozytariuszy i interesariuszy. Pamiętać należy jednak, że obie te grupy wzajemnie się przenikają, w związku z czym depozytariusz może być jednocześnie interesariuszem i na odwrót. W tym kontekście edukacja $\mathrm{z}$ zakresu dziedzictwa postrzegana jest jako jedna $\mathrm{z}$ podstaw przedsiębiorczości regionalnej, obszar innowacji i konkurencyjności, czy też produkt rynkowy wpływający na jakość życia w regionie.

Edukacja zorientowana na interesariuszy przyczyniła się do podniesienia wiedzy, umiejętności oraz integracji mieszkańców Warmii i Mazur. Umożliwiło to rozwój lokalnych produktów ekonomicznych, usług gastronomicznych, hotelarskich, turystycznych oraz edukacyjnych. Natomiast edukacja ukierunkowana na depozytariuszy stała się czynnikiem wzrostu kapitału wiedzy odbiorców: wielopokoleniowego społeczeństwa województwa warmińsko-mazurskiego, a także przedstawicieli innych regionów, krajów i kultur. Z ekonomicznego punktu widzenia tak przedstawione działania realizowane za pośrednictwem wiosek tematycznych na Warmii i Mazurach: mają charakter pozaużytkowy, tzn. dotyczą wartości obiektów materialnych i spuścizn niematerialnych mających znaczenie dla kształtowania tożsamości regionalnej; umożliwiają przyszłym pokoleniom korzystanie z zasobów historycznych i kulturowych; utrwalają i ochraniają dziedzictwo oraz generują dobra, towary i usługi.

Tabela 3. Edukacja z zakresu dziedzictwa kulturowego regionu Warmii i Mazur

\begin{tabular}{|c|c|}
\hline Odbiorcy edukacji & Rodzaj działania \\
\hline Interesariusze & $\begin{array}{l}\text { - Warsztaty z zakresu dziedzictwa: kulturowego regionu Warmii } \\
\text { i Mazur, przyrodniczego, kulinarnego oraz ekonomii społecznej } \\
\text { - Zajęcia artystyczne: fotograficzne, malarskie, rzeźbiarskie, garncarskie } \\
\text { - Edukacja z zakresu: rzemiosła, dawnych zawodów (leśnika, rolnika, } \\
\text { rybaka) } \\
\text { - Uczestnictwo w ofertach szkoleniowych i warsztatowych lokalnego } \\
\text { NGO }\end{array}$ \\
\hline Depozytariusze & $\begin{array}{l}\text { - Warsztaty regionalne z zakresu: historii i kultury Warmii i Mazur, } \\
\text { kulinariów regionalnych, strzyżenia owiec } \\
\text { - Warsztaty artystyczne: malarskie, rzeźbiarskie, garncarskie, mydlarskie } \\
\text { - Szlaki dawnych zawodów, np. Szlak Starego Mazura } \\
\text { - Gry edukacyjne z wykorzystaniem dawnych zabawek i gier } \\
\text { - Izby pamięci, np. Marii Zientary Malewskiej w Brąswałdzie } \\
\text { - Konkursy: recytatorskie, historyczne, artystyczne, muzyczne } \\
\text { - Zielone szkoły } \\
\text { - Edukacja ekologiczna, np. Ekologiczne Wieczory } \\
\text { - Konferencje naukowe/popularno-naukowe } \\
\text { - Spotkania przedstawicieli społeczności 60+ } \\
\text { - Zjazdy grup zawodowych } \\
\text { - Projekty międzynarodowe } \\
\text { - Spotkania wielokulturowe } \\
\text { - Ścieżki edukacyjno-historyczne i przyrodnicze } \\
\text { - Parki linowe } \\
\text { - Skanseny, np. ekoskansen narzędzi rolniczych } \\
\text { - Szlaki kulturowe, turystyczne i przyrodnicze } \\
\text { - Produkty wydawnicze: pozycje popularno-naukowe i naukowe, } \\
\text { scenariusze zajęć }\end{array}$ \\
\hline
\end{tabular}

Źródło: opracowanie własne 
Wykorzystanie potencjału dziedzictwa kulturowego Warmii i Mazur w perspektywie ekonomicznej działalności wiosek tematycznych uzależnione jest od szeregu czynników endogenicznych, w których główną rolę odgrywają: lokalni liderzy projektujący i wdrażający regionalną strategię rozwojową; wszelkie instytucje samorządowe oraz organizacje i stowarzyszenia o zasięgu lokalnym skupiające się na wsparciu przedsiębiorczości z wykorzystaniem zasobu kulturowego. Determinantem dobrych praktyk i odpowiedniej kondycji wiosek tematycznych są także ludzie - społeczność - inicjatywy oddolne. Wzrost kapitału wiedzy mieszkańców obszarów wiejskich oraz ich większa mobilność w edukacji, popularyzacji i upowszechnianiu dziedzictwa regionalnego jako interesariuszy i depozytariuszy jest szansą na rozwój innowacyjnej ekonomii lokalnej. Jednocześnie wśród głównych czynników rozwijających działalność wiosek tematycznych na Warmii i Mazurach wskazuje się takie obszary, jak: realizacja szkoleń; pomoc w inicjowaniu pomysłów rozwijających ofertę wsi; dzielenie się dobrymi praktykami z innymi wsiami; wspólna promocja $\mathrm{z}$ innymi wsiami; wsparcie ze strony gminy oraz urzędu marszałkowskiego; pomoc przy tworzeniu ofert regionalnych; wsparcie finansowe.

Tabela 4. Obszary wsparcia jako czynnik rozwoju wsi tematycznych na Warmii i Mazurach

\begin{tabular}{|c|c|}
\hline Obszary wsparcia & Charakterystyka \\
\hline Szkolenia & $\begin{array}{l}\text { - Aktywizacja mieszkańców wioski - wsi tematycznych } \\
\text { - Szkolenia z zakresu: dziedzictwa kulturowego regionu } \\
\text { (lokalnego kapitału wiedzy), ekonomii społecznej, wdrażania } \\
\text { edukacji regionalnej oraz pracy liderów }\end{array}$ \\
\hline Inicjowanie pomysłów & $\begin{array}{l}\text { - Kontakt z przedstawicielami innych wiosek tematycznych } \\
\text { - Praca z ekspertami i specjalistami }\end{array}$ \\
\hline $\begin{array}{l}\text { Dzielenie się dobrymi } \\
\text { praktykami }\end{array}$ & $\begin{array}{l}\text { - Organizacja wizyt studyjnych w innych wsiach } \\
\text { - Nawiązanie kontaktów z liderami wiosek tematycznych }\end{array}$ \\
\hline Wspólna promocja & $\begin{array}{l}\text { - Wypracowanie wspólnych działań promujących produkty } \\
\text { współpracujących ze sobą wiosek tematycznych }\end{array}$ \\
\hline Wsparcie ze strony gminy & $\begin{array}{l}\text { - Pomoc w procesie ekonomizacji osób fizycznych i prawnych } \\
\text { - Dostęp do lokali na preferencyjnych warunkach } \\
\text { - Wsparcie rzeczowe } \\
\text { - Pomoc w zabezpieczeniu wkładów własnych w realizowanych } \\
\text { zadaniach i projektach oraz w globalnej promocji } \\
\text { - Zlecanie zadań publicznych }\end{array}$ \\
\hline $\begin{array}{l}\text { Wsparcie ze strony urzędu } \\
\text { marszałkowskiego }\end{array}$ & $\begin{array}{l}\text { - Ujmowanie zakresu działań wiosek tematycznych w konkursach } \\
\text { na realizację ofert organizacji pozarządowych w regionie } \\
\text { - Pomoc w promocji wiosek tematycznych } \\
\text { - Zlecanie zadań publicznych }\end{array}$ \\
\hline $\begin{array}{l}\text { Pomoc przy tworzeniu } \\
\text { ofert regionalnych }\end{array}$ & $\begin{array}{l}\text { - Pomoc przy tworzeniu spójnych ofert i produktów } \\
\text { turystycznych oraz promocji } \\
\text { - Opieka ekspertów i specjalistów }\end{array}$ \\
\hline Wsparcie finansowe & - Pomoc w utrzymaniu infrastruktury - remonty i modernizacja \\
\hline
\end{tabular}

Źródło: opracowanie własne

Wioski tematyczne działające na terenie województwa warmińsko-mazurskiego potrzebują zaangażowania i pomocy instytucji samorządowych oraz mediów lokalnych $\mathrm{w}$ upowszechnianiu, popularyzacji, reklamie działalności edukacyjnej, turystycznej i ekonomicznej. Badani określili swoją współpracę z poszczególnymi podmiotami lokalnymi 
i centralnymi w postaci ocen w skali $0-5$, a uśrednione wyniki przedstawione zostały na rycinie $1 . \mathrm{Z}$ analizy zebranego materiału wynika, że wioski tematyczne w największym stopniu (ocena 4) korzystają ze wsparcia: samorządu lokalnego, urzędu marszałkowskiego, organizacji pozarządowych. W mniejszym zakresie (3) prowadzą działania na podstawie współpracy z: mediami lokalnymi i regionalnymi, lokalnym biznesem, Kościołem lub związkami wyznaniowymi. Najmniej kooperują z urzędami centralnymi (2) oraz urzędem wojewódzkim i mediami ogólnopolskimi (1). Jednocześnie żadna z badanych wiosek nie wskazała na brak nawiązywania współpracy z jakimkolwiek podmiotem lokalnym i centralnym.

W województwie warmińsko-mazurskim istnieje potrzeba budowania sieci powiązań pomiędzy instytucjami samorządowymi - organizacjami pozarządowymi - podmiotami ekonomii społecznej - inicjatywami oddolnymi - liderami w obszarze regionalnym. Wioski tematyczne sporadycznie otrzymują wsparcie z grantów unijnych i dotacji ogólnopolskich. Najczęściej dotyczy to finansowania małych projektów miękkich. Ich głównym źródeł utrzymania jest własna działalność ekonomiczna w sektorze turystyki i edukacji, sprzedaż produktów lokalnych oraz dotacje w ramach konkursów i dofinansowań regionalnych.

Badani wyróżniają także charakterystyczne ograniczenia i zagrożenia dla rozwoju przedsiębiorczości w regionie: słabą współpracę sieciową podmiotów i osób we wsi; zbyt małe włączenie mieszkańców w realizację działań edukacyjno-ekonomicznych wsi; brak wspólnego (wewnątrzspołecznego) planowania działań oraz aktywnego lidera (częste zmęczenie liderów); niewielką liczba mieszkańców (wyludnianie i starzenie się społeczeństwa) oraz trudności w pozyskiwaniu środków finansowych.

Rycina 1. Średnia ocena współpracy wiosek tematycznych z przedstawicielami instytucji

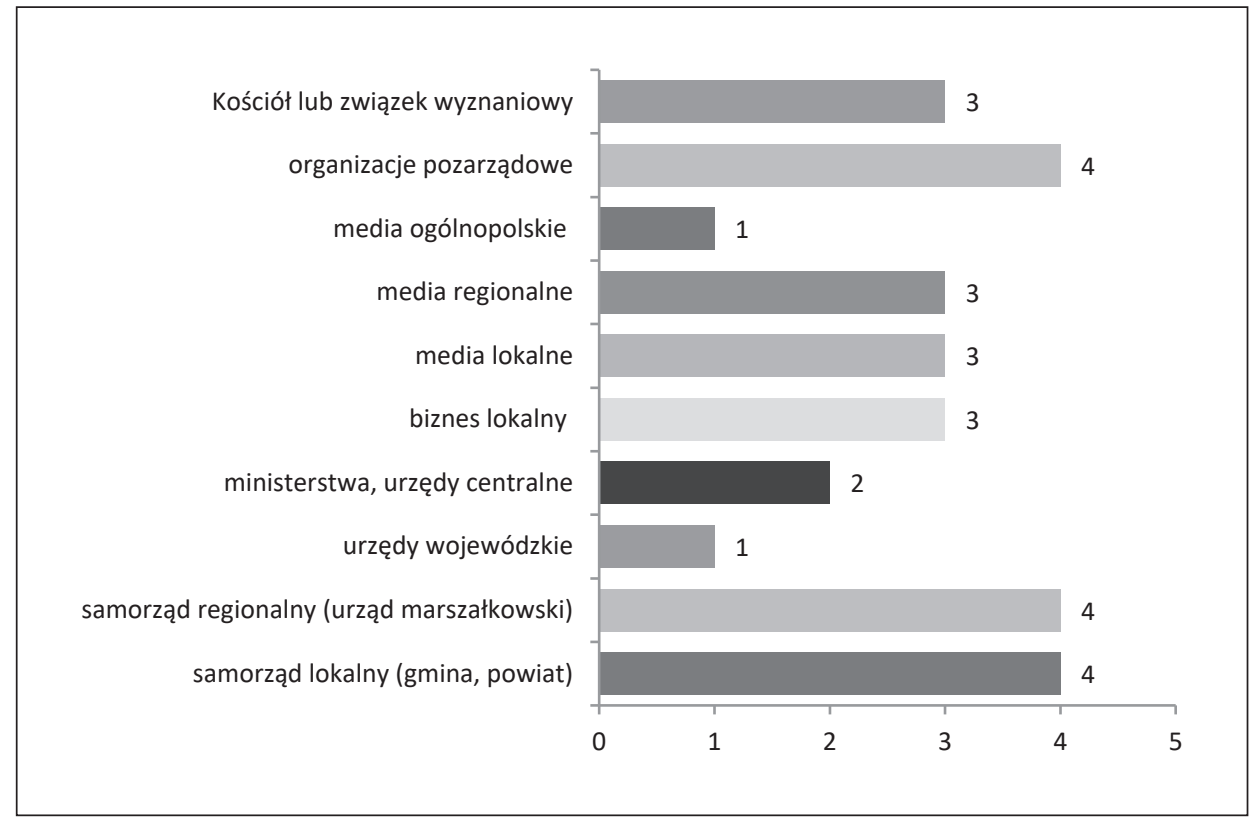

Źródło: opracowanie własne 


\section{Zakończenie}

Wioski tematyczne to jedna z nowych metod rozwoju przedsiębiorczości obszarów wiejskich w Polsce. Oczywiście w żadnym wypadku nie można ich traktować jako remedium na rozwiązanie wszystkich problemów wsi, bowiem skuteczność funkcjonowania tego typu miejscowości zależy od wielu czynników.

Przeprowadzone badania pozytywnie weryfikują postawioną we wstępie tezę, że wioski tematyczne dzięki różnorodnym działaniom edukacyjnym i przedsiębiorczym w istotny sposób przyczyniają się do ożywienia, innowacyjności i rozwoju gospodarki wiejskiej w regionie Warmii i Mazur. Przedsiębiorczość lokalna budowana przez dobre przykłady takich wiosek to ważny czynnik rozwoju regionalnego, zaś aktywne uczenie się na podstawie kompetencji propagujących przedsiębiorczość to innowacyjny model edukacji społeczeństwa wielopokoleniowego.

Funkcjonowanie wiosek tematycznych na obszarach wiejskich województwa warmińsko-mazurskiego przynosi mieszkańcom wsi szereg korzyści społeczno-ekonomicznych oraz społeczno-kulturowych, tzn. odgrywa znaczną rolę w rozwoju przestrzeni wiejskiej, aktywizacji na rzecz dziedzictwa, ekonomii regionalnej, sieci lokalnych powiązań oraz wykorzystywania lokalnych zasobów.

Każdy z tych podmiotów ekonomii społecznej ma określone rodzaje specjalizacji, przez które kształtuje urozmaicone oferty usług i produktów. Wpływa to na dynamikę ożywienia wsi, przyciąga turystów, a także generuje popyt, stwarzając możliwość rozwoju innych branż w regionie. Przez promocję własnych inicjatyw i ofert wioski tematyczne uczestniczą w marketingu miejsc, przyczyniają się do ich pozytywnego rozwoju oraz podnoszą atrakcyjność turystyczną, gospodarczą i społeczno-kulturową wsi, a także - całego regionu. Stają się one jednocześnie determinantem rozwoju lokalnej infrastruktury oraz podwyższenia standardów i warunków życia mieszkańców wsi Warmii i Mazur. Wskazują na to nowa, zagospodarowana przestrzeń wiejska oraz nowe lub odnowione budynki użyteczności publicznej.

Działalność wiosek tematycznych z bogatą ofertą edukacji regionalnej na Warmii i Mazurach odegrała znaczącą rolę w rozwoju lokalnych podmiotów ekonomii społecznej oraz przyczyniła się do powstania ekonomicznych i edukacyjnych produktów lokalnych, w tym ofert turystycznych i gastronomicznych. W wielu wsiach pojawiły się dodatkowe miejsca pracy, co wpłynęło na zmniejszenie poziomu bezrobocia oraz wzrost dochodów mieszkańców. Mieszkańcy społeczności lokalnej nabyli nowe kompetencje oraz umiejętności społeczne i zawodowe, poprawiając tym samym swoją pozycję na rynku pracy. Rozumiany w ten sposób wzrost kapitału wiedzy mieszkańców Warmii i Mazur oraz ich większa mobilność w edukacji i upowszechnianiu dziedzictwa regionalnego jako interesariuszy i depozytariuszy stanowią szansę na dalszy rozwój innowacyjnej ekonomii lokalnej.

Szeroka oferta edukacyjna badanych wiosek odgrywa coraz większą rolę w kształtowaniu osobowości jednostki, co prowadzi do wzrostu kapitału ludzkiego społeczności lokalnej. Oferty te tworzą również zasób dla rozwoju kapitału społecznego w postaci społecznej aktywizacji, angażowania się obywateli w opiekę nad dziedzictwem oraz współpracy i współdziałania na rzecz ochrony i użytkowania dziedzictwa. Poznawanie historii i tradycji przyczynia się do wzrostu zaufania społecznego do tego typu inicjatyw z obszaru przedsiębiorczości regionalnej. 
Przeprowadzane badania wskazują także, że główne czynniki warunkujące działalność wiosek tematycznych na Warmii i Mazurach, tzn.: przeprowadzanie szkoleń, pomoc w inicjowaniu pomysłów rozwijających ofertę wsi, dzielenie się dobrymi praktykami z innymi wsiami, wspólna promocja $\mathrm{z}$ innymi wsiami, wsparcie ze strony jednostek samorządu terytorialnego, pomoc przy tworzeniu ofert regionalnych, a także wsparcie finansowe, prowadzą do tworzenia tzw. lokalnych sieci powiązań pomiędzy instytucjami samorządowymi - organizacjami pozarządowymi - podmiotami ekonomii społecznej inicjatywami oddolnymi - liderami w obszarze regionalnym, które to powiązania są gwarantem rozwoju lokalnej przedsiębiorczości społecznej.

Literatura

References

Czapniewska, G. (2018). Wioski tematyczne w procesie odnowy wsi pomorskich. Studia Obszarów Wiejskich, 49, 155-171. doi: 10.7163/SOW.49.10

Hełpa-Liszkowska, K. (2013). Dziedzictwo kulturowe jako czynnik rozwoju lokalnego. Studia Oeconomica Posnaniensia, 6(255), 5-18.

Malec-Kornajew, Ł., Kania, J. (2015). Sztuka na wsi. Alternatywne możliwości dla turystyki wiejskiej. W: W. Kamińska (red.), Innowacyjność w turystyce wiejskiej a nowe możliwości zatrudnienia na obszarach wiejskich. Warszawa: Komitet Przestrzennego Zagospodarowania Kraju PAN, 83-102.

Kłoczko-Gajewska, A., Markiewicz, O. (2018). Mechanizm rozprzestrzeniania się wiosek tematycznych w Polsce. Wieś i Rolnictwo, 80(3), 193-210. doi: 10.7366/wir032018/09

Idziak, M. (2019, 28 listopada). Wioski tematyczne w Polsce w latach 1997-2013. Pozyskano z: http:// www.wioskitematyczne.org.pl/files/Wioski\%20tematyczne\%201997\%20-\%202013.pdf

Idziak, W. (2008). Wymyślić wieś od nowa. Wioski tematyczne. Koszalin: Alta Press.

Jankowski, D. (2019). Edukacja regionalna jako czynnik regionotwórczy. W: S. Dąbrowski, A. Kociszewski (red.), Regionalizm polski. Ciechanów: Wydawnictwo ZRTK, 90-112.

Kowalska, N. (2019). Wioski tematyczne jako przykład innowacji w turystyce na terenie pogórniczym. Turystyka Kulturowa, 4, 7-19.

Kozioł, L., Karaś, A. (2015). The Concept of the Tourism Enterprise Innovation Analysis. Zeszyty Naukowe Uniwersytetu Szczecińskiego. Ekonomiczne Problemy Turystyki, 4(32), 19-29.

Legutko-Kobus, P. (2016). Dziedzictwo kulturowe jako czynnik rozwoju i specjalizacji regionów. Studia KPZK, 170, 140-157.

Loxley, J. (2007). Transformingor Reforming Capitalism: Towards a Theory of Community Economic Development. Halifax: Fernwood Publishing.

Łojko, M. (2011). Przedsiębiorczość agroturystyczna mieszkańców wsi szansą aktywizacji i rozwoju obszarów wiejskich. Zeszyty Naukowe Ostrołęckiego Towarzystwa Naukowego, 25, 463-473.

Pearce, J. (2003). Social Enterprise in Anytown. London: Calouste Gunbelkian Foundation.

Podołowski, G. (2011). Działalność agroturystyczna szansą rozwoju obszarów wiejskich. Turystyka i Rekreacja, 7(1), 115-124.

Purchla, J. (2011). Dziedzictwo kulturowe a kapitał społeczny. Małopolskie Studia Regionalne, 1(21), 5-8.

Roman, M., Niedziółka, A. (2017). Agroturystyka jako forma przedsiębiorczości na obszarach wiejskich. Warszawa: Wydawnictwo SGGW.

Sala, K. (2016). Wioski tematyczne jako przykład innowacyjności w turystyce wiejskiej. Zeszyty Naukowe Małopolskiej Wyższej Szkoły Ekonomicznej w Tarnowie, 30(2), 117-126.

Sowier-Kasprzyk, I. (2011). Promocja turystyki aktywnej na przykładzie gminy Mstów. Zeszyty Naukowe Ostrołęckiego Towarzystwa Naukowego, 25, 141-154.

Wacięga, S. (2011). Przedsiębiorczość obywatelska w działalności wioski tematycznej. Folia Pomeranae Universitatis TechnologiaeStietinensis. Seria Oeconomica, 288(64), 81-90. 
Majka Łojko, dr, Uniwersytet Warmińsko-Mazurski w Olsztynie, Wydział Nauk Ekonomicznych, Instytut Ekonomii i Finansów, Katedra Polityki Gospodarczej. Zajmuje się problematyką naukowo-badawczą z obszaru ekonomii społecznej, rynku pracy i systemu pomocy społecznej. Autorka i współautorka publikacji naukowych, w tym monografii, raportów badawczych i artykułów z pogranicza polityki społecznej i ekonomii społecznej. W ramach Zespołu ds. Współpracy Nauki i Ekonomii Społecznej działającego przy Regionalnym Komitecie Rozwoju Ekonomii Społecznej województwa warmińsko-mazurskiego współrealizuje działania związane z promocją i upowszechnianiem wiedzy na temat sektora ekonomii społecznej w regionie Warmii i Mazur.

Majka Łojko, PhD, University of Warmia and Mazury in Olsztyn, Faculty of Economic Sciences, Institute of Economics and Finance, Department of Economic Policy. In her research she deals with social economy, labour market and social assistance system. Author and co-author of academic publications, including monographs, research reports and articles on the border of social policy and social economy. As part of the Team for the Cooperation of Science and Social Economy operating at the Regional Committee for the Development of Social Economy of the Warmińsko-Mazurskie Voivodeship co-implements activities related to the promotion and dissemination of knowledge about the social economy sector in the region of Warmia and Mazury.

ORCID: https://orcid.org/0000-0003-4801-8069

\title{
Adres/Address:
}

Uniwersytet Warmińsko-Mazurski w Olsztynie

Wydział Nauk Ekonomicznych, Instytut Ekonomii i Finansów

Katedra Polityki Gospodarczej

ul. M. Oczapowskiego 4

10-719 Olsztyn, Polska

e-mail: majka.lojko@uwm.edu.pl

Kinga Lisowska, dr, Uniwersytet Warmińsko-Mazurski w Olsztynie, Wydział Nauk Społecznych, Instytut Nauk Pedagogicznych, Katedra Pedagogiki Ogólnej i Opiekuńczej. Zajmuje się problematyką naukowo-badawczą z zakresu: dziejów oświaty polskiej, edukacji regionalnej i pedagogiki chrześcijańskiej. Autorka i współautorka monografii oraz publikacji naukowych z dziejów oświaty i wychowania oraz dziedzictwa kulturowego regionu Warmii i Mazur. Jest członkiem Zarządu Polskiego Towarzystwa Historycznego Oddział w Olsztynie, odpowiedzialnym za upowszechnianie i edukację regionalną i obywatelską w województwie warmińsko-mazurskim.

Kinga Lisowska, PhD, University of Warmia and Mazury in Olsztyn, Faculty of Social Sciences, Institute of Pedagogical Sciences, Department of General and Caring Pedagogy. In her work she deals with the history of Polish education, regional education and Christian pedagogy. Author, co-author of monographs and academic publications on the history of education and upbringing and cultural heritage of the Warmia and Mazury. Member of the Board of the Polish Historical Society Branch in Olsztyn, responsible for dissemination and regional and civic education in the Warmińsko-Mazurskie Voivodeship.

ORCID: https://orcid.org/0000-0002-8404-4363

\author{
Adres/Address: \\ Uniwersytet Warmińsko-Mazurski w Olsztynie \\ Wydział Nauk Społecznych, Instytut Nauk Pedagogicznych \\ Katedra Pedagogiki Ogólnej i Opiekuńczej \\ ul. Żołnierska 14 a \\ 10-561 Olsztyn, Polska \\ e-mail: kinga.lisowska@uwm.edu.pl
}

